\title{
Evolution of Mg-Al-based Inclusions with Changes in Mg Content during Ladle Treatment Based on a Coupled Reaction Model
}

\author{
Jeong-In KIM and Sun-Joong KIM* \\ Department of Material Science \& Engineering, Chosun University, 309, Pilmun-daero, Dong-gu, Gwangju, 61452 Republic of \\ Korea.
}

(Received on August 16, 2019; accepted on September 24, 2019)

\begin{abstract}
In the steelmaking process, $\mathrm{MgAl}_{2} \mathrm{O}_{4}$ spinel inclusions diminish steel qualities and cause nozzle clogging based on the high melting point and low deformation of $\mathrm{MgAl}_{2} \mathrm{O}_{4}$. Typically, $\mathrm{MgAl}_{2} \mathrm{O}_{4}$ spinel inclusions are generated from $\mathrm{Al}_{2} \mathrm{O}_{3}$ inclusions with increasing $\mathrm{MgO}$ content, meaning ladle treatment does not represent an equilibrium state. However, complex reactions simultaneously occur between molten steel, slag, inclusions, refractory, and alloying elements during ladle treatment. Therefore, it is necessary to develop a kinetic model to predict compositional changes in molten steel, slag, and the inclusions during ladle treatment. Such a kinetic model must be able to simulate the generation of $\mathrm{MgAl}_{2} \mathrm{O}_{4}$ spinel inclusions from $\mathrm{Al}_{2} \mathrm{O}_{3}$ to control such inclusions. Additionally, $\mathrm{MgAl}_{2} \mathrm{O}_{4}$ spinel inclusions can evolve into MgO-rich inclusions with gradually increasing $\mathrm{MgO}$ content in $\mathrm{Mg}-\mathrm{Al}$-based inclusions. In this study, we developed an enhanced kinetic model based on a coupled reaction model with the compositional changes in $\mathrm{Mg}-\mathrm{Al}$ based inclusions. We also investigated the influence of the $\mathrm{CaO} / \mathrm{SiO}_{2}$ ratio in slag on the generation of spinel inclusions under industrial conditions for a 210-ton steel sample.
\end{abstract}

KEY WORDS: ladle treatment; coupled reaction model; slag basicity; $\mathrm{MgAl}_{2} \mathrm{O}_{4}$ spinel inclusions; $\mathrm{MgO}$ inclusions.

\section{Introduction}

In the steelmaking process, non-metallic inclusions weaken the physicochemical properties of steel products. In particular, $\mathrm{MgAl}_{2} \mathrm{O}_{4}$ spinel inclusions are harmful inclusions because they can lower the quality of final steel products based on the high melting point and low deformation of $\mathrm{MgAl}_{2} \mathrm{O}_{4}{ }^{1,2)}$ Furthermore, $\mathrm{MgAl}_{2} \mathrm{O}_{4}$ has a stronger adhesive tendency with nozzle materials compared to $\mathrm{Al}_{2} \mathrm{O}_{3}$ and $\mathrm{MgO}{ }^{3)}$ Therefore, spinel inclusions influence nozzle clogging, which can lead to operational problems, meaning spinel inclusions must be controlled and suppressed during ladle treatment.

Many previous studies have analyzed spinel formation mechanisms experimentally. Nishi and Shinme ${ }^{4}$ forced spinel generation from $\mathrm{Al}_{2} \mathrm{O}_{3}$ inclusions using $15 \mathrm{~kg}$ of SUS 304 under an Ar gas flow in a high-frequency induction furnace. They reported that even with an $\mathrm{Mg}$ content in steel of less than 1 ppm by mass, the $\mathrm{MgO}$ content in $\mathrm{Al}_{2} \mathrm{O}_{3}$ inclusions increased after $\mathrm{Al}$ de-oxidation based on reactions with $\mathrm{Mg}$. This indicates that $\mathrm{Al}_{2} \mathrm{O}_{3}$ inclusions evolve into spinel inclusions with increasing $\mathrm{MgO}$ content, which is supplied by the $\mathrm{Mg}$ in steel. Okuyama et al ${ }^{5)}$ investigated the influence of $\mathrm{MgO}$ in slag on spinel generation using 20 $\mathrm{kg}$ of molten steel containing $16 \% \mathrm{Cr}-0.1 \% \mathrm{Al}$ under an $\mathrm{Ar}$ gas flow in a high-frequency vacuum induction furnace.

\footnotetext{
* Corresponding author: E-mail: ksjoong@Chosun.ac.kr DOI: https://doi.org/10.2355/isijinternational.ISIJINT-2019-488
}

They discovered that the increasing $\mathrm{MgO}$ content in $\mathrm{Al}_{2} \mathrm{O}_{3}$ inclusions is supplied by the $\mathrm{Mg}$ in steel based on the reduction of $\mathrm{MgO}$ in slag. Additionally, they evaluated the influence of the $\mathrm{CaO} / \mathrm{SiO}_{2}$ ratio in slag on spinel generation. They reported that the $\mathrm{MgO}$ content in $\mathrm{Al}_{2} \mathrm{O}_{3}$ inclusions increased when the $\mathrm{CaO} / \mathrm{SiO}_{2}$ ratio increased. Harada et $a l .{ }^{6)}$ analyzed the influence of the $\mathrm{CaO} / \mathrm{SiO}_{2}$ ratio in slag on spinel generation using $30 \mathrm{~kg}$ of molten steel under an Ar gas flow. According to their results, the $\mathrm{MgO}$ content in $\mathrm{Al}_{2} \mathrm{O}_{3}$ inclusions increased following $\mathrm{Al}$ addition and spinel inclusions were observed. Furthermore, when the $\mathrm{CaO} / \mathrm{SiO}_{2}$ ratio in slag increased, the activity of $\mathrm{MgO}$ in the slag and the diffusivity rate of $\mathrm{Mg}$ in the steel also increased. Park and $\mathrm{Kim}^{7)}$ studied the effects of $\mathrm{CaO}-\mathrm{Al}_{2} \mathrm{O}_{3}-\mathrm{MgO}$ system slag on spinel generation using $\mathrm{Fe}-16 \% \mathrm{Cr}$ ferritic stainless steel. MgO-rich inclusions were observed in their research, indicating that $\mathrm{MgO}$-rich inclusions can be generated in addition to spinel inclusion. Todoroki and Mizuno ${ }^{8)}$ investigated the influence of $\mathrm{MgO}$-containing slag with $\mathrm{Al}$ content on spinel generation in the steelmaking process. They also analyzed the morphology of inclusions, including spinel and $\mathrm{MgO}$-rich inclusions. Harada et al..$^{9)}$ evaluated the dissolution of $\mathrm{MgO}$ in a crucible in terms of spinel generation. They observed the formation of spinel inclusions without the addition of $\mathrm{Mg}$ or $\mathrm{MgO}$-containing slag. Liu et al. ${ }^{10)}$ reported the influence of $\mathrm{MgO}$-based refractory on spinel generation based on an experiment on the rotation of a $\mathrm{MgO}$ rod. They discovered that $\mathrm{MgO}$-based refractory can supply the $\mathrm{Mg}$ content in steel, resulting in spinel generation. 
Furthermore, in another study, ${ }^{11)}$ it was concluded that the diffusivity of $\mathrm{MgO}$ led to spinel generation on the surface of an $\mathrm{Al}_{2} \mathrm{O}_{3}$ rod.

$$
3[\mathrm{Mg}]+4\left(\mathrm{Al}_{2} \mathrm{O}_{3}\right)_{\text {Inc. }}=3\left(\mathrm{MgAl}_{2} \mathrm{O}_{4}\right)_{\text {Inc. }}+2[\mathrm{Al}] \ldots \ldots \text { (1) }
$$

Based on the studies above, Eq. (1) represents the formation mechanism of spinel generation. First, $\mathrm{Al}_{2} \mathrm{O}_{3}$ inclusions are generated by $\mathrm{Al}$ de-oxidation. $\mathrm{Al}_{2} \mathrm{O}_{3}$ inclusions evolve into $\mathrm{MgAl}_{2} \mathrm{O}_{4}$ spinel inclusions through reactions with the $\mathrm{Mg}$ content in steel, which is supplied by the reduction of slag and dissolution of $\mathrm{MgO}$-based refractory. Additionally, if the $\mathrm{MgO}$ content in spinel inclusions increases gradually, $\mathrm{MgO}$-rich inclusions can be generated from spinel inclusions. Therefore, the evolution of $\mathrm{Mg}-\mathrm{Al}$-based inclusions indicates that ladle treatment does not represent an equilibrium state.

However, during ladle treatment, complex reactions simultaneously occur between molten steel, slag, inclusions, refractory, and alloying additions. Therefore, it is nontrivial to control and suppress the behaviors of spinel generation during ladle treatment. Therefore, a kinetic model is required to predict compositional changes in molten steel, slag, and inclusions during ladle treatment. Previous studies have developed such kinetic models. For example, Peter et al. ${ }^{12)}$ presented the Metsim model, which can simulate industrial-scale samples sizes of 123 tons and 151 tons. This model can calculate compositional changes in molten steel and slag based on the mass transfer determined by Ar flow rate. Shu et al. ${ }^{13,14)}$ developed a ladle tank recirculation model called the Inclusion Composition in Steel (ICS) model. In this model, the ladle furnace is divided into several tanks that are circulated using the stirring energy generated by an Ar flow. This model can predict compositional changes in molten steel, slag, and inclusions, such as $\mathrm{Al}_{2} \mathrm{O}_{3}, \mathrm{MgAl}_{2} \mathrm{O}_{4}, \mathrm{CaO} \cdot 6 \mathrm{Al}_{2} \mathrm{O}_{3}$, and $\mathrm{CaO}-\mathrm{MgO}-\mathrm{Al}_{2} \mathrm{O}_{3}$, based on a 210-ton sample size. Van Ende et al. ${ }^{15)}$ presented the Effective Equilibrium Reaction Zone (EERZ) model. In the EERZ model, the volume of the reaction interface area is considered for reactions between steel and slag. The volume of the reaction interface area can also be applied as the mass transfer. This model is reliable for a sample size of 165 tons and can simulate the generation of $\mathrm{Al}_{2} \mathrm{O}_{3}, \mathrm{MgAl}_{2} \mathrm{O}_{4}, \mathrm{CaO} \cdot 3 \mathrm{Al}_{2} \mathrm{O}_{3}$, and $\mathrm{CaO} \cdot 6 \mathrm{Al}_{2} \mathrm{O}_{3}$ inclusions, as well compositional changes in steel and slag. Ren et al. ${ }^{16-19)}$ developed a kinetic model based on FactSage macro processing to predict the formation of inclusions using A1killed steel and Al-Ti-killed steel. The reactions between steel and inclusions were assumed to be equilibrated, and the reactions between bulk area and interface area in steel and slag were simulated by mass transfer. In the case of $\mathrm{Ca}$ treatment, the molten steel zone was divided into the Ca-rich zone and the bulk steel zone, and their model showed the reliability to simulate the formation of $\mathrm{CaO}-\mathrm{Al}_{2} \mathrm{O}_{3}$ and $\mathrm{CaS}$ inclusions based on the data of 311-ton scale. Furthermore, the amounts of $\mathrm{Al}_{2} \mathrm{O}_{3}, \mathrm{Al}_{2} \mathrm{O}_{3}-\mathrm{TiO}_{\mathrm{x}}$ and $\mathrm{SiO}_{2}-\mathrm{MnO}-\mathrm{FeO}$ inclusions can be calculated with their model. The kinetic model can be applied for the tundish process based on 25-ton scale, then the compositions of $\mathrm{Al}_{2} \mathrm{O}_{3}, \mathrm{CaO}, \mathrm{MgO}$ and $\mathrm{CaS}$ in inclusions were evaluated. ${ }^{19)}$ Harada et al. ${ }^{20-22)}$ developed a kinetic model called the $L F$ model based on coupled reactions. This model considers the complex reac- tions between molten steel, slag, inclusions, refractory, and alloying elements. Reactions between molten steel and slag, and between molten steel and inclusions originating from slag are calculated using the double-film theory. ${ }^{23,24)}$ This model can simulate compositional changes in steel, slag, and inclusions, such as $\mathrm{Al}_{2} \mathrm{O}_{3}, \mathrm{MgAl}_{2} \mathrm{O}_{4}, \mathrm{CaO} \cdot \mathrm{Al}_{2} \mathrm{O}_{3}$, and $\mathrm{MnO} \cdot \mathrm{SiO}_{2}$, based on three inclusion behaviors using a sample size of 165 tons. However, a kinetic model considering the compositional changes in $\mathrm{Mg}-\mathrm{Al}$-based inclusions has not been reported.

In this study, we enhanced a kinetic model based on coupled reactions to predict compositional changes in steel, slag, and inclusions during ladle treatment. In the enhanced model, compositional changes in $\mathrm{Mg}-\mathrm{Al}$-based inclusions resulting from $\mathrm{Al}_{2} \mathrm{O}_{3}$ and $\mathrm{MgO}$ inclusions are considered. We investigated the kinetic model to clarify the influence of the $\mathrm{CaO} / \mathrm{SiO}_{2}$ ratio in slag on spinel generation under industrial conditions with a 210 -ton sample size.

\section{Model Description}

Figure 1 presents a schematic diagram of the enhanced kinetic model based on coupled reactions (also referred to as the coupled reaction model) for simulating the reactions between molten steel, molten slag, inclusions, refractory, and alloying additions. The details of reactions and inclusion behaviors in the model have been described in previous publications. ${ }^{20-22)}$ In the coupled reaction model, the following four main types of reactions and three types of inclusion behaviors were considered:

(a) Reactions between molten steel and slag

(b) Reactions between slag and inclusions originating from slag

(c) Dissolution of refractory material into the molten steel and slag phase

(d) De-oxidation reactions based on the addition of alloying elements

(e) Inclusion behaviors
A. Flotation of de-oxidation products and inclusion originating from slag
B. Entrapment of slag
C. Agglomeration of inclusions

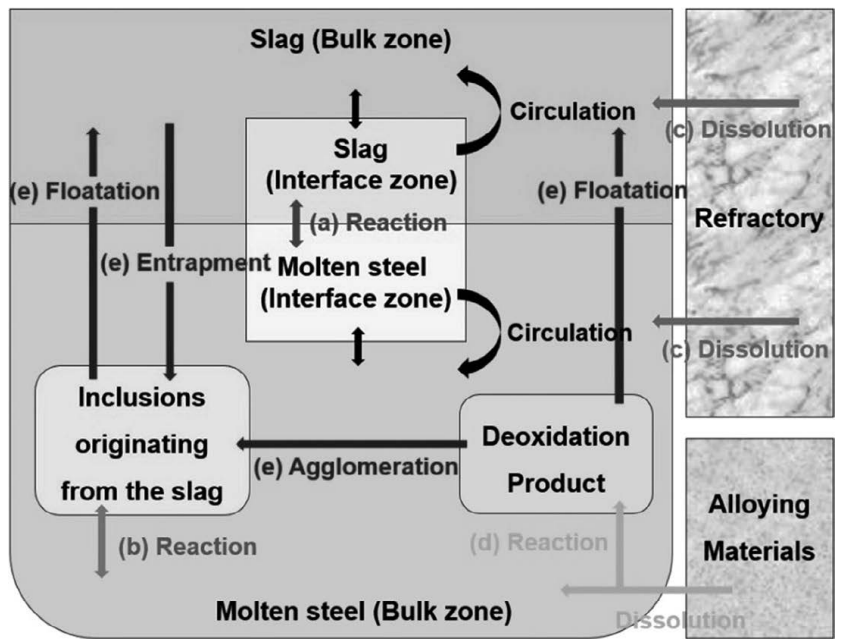

Fig. 1. Schematic diagram of the enhanced kinetic model (coupled reaction model). 
In this paper, the original coupled reaction model and the improvements implemented in this study are described. Reactions (a) and (b) were calculated based on the doublefilm theory. ${ }^{23,24)} \mathrm{A}$ phase can be divided into a bulk zone and interface zone, such as the steel phase and slag phase in Fig. 1 , and reactions in the interface zones of adjacent phases are assumed to be equilibrated. The reactions between the bulk zone and interface zone in each phase are considered as flux density in terms of mass transfer. The mass transfer coefficient of each component is calculated based on stirring energy using the Ar flow rate and conditions of the ladle furnace.

In previous models, the components in the slag were $\mathrm{CaO}, \mathrm{SiO}_{2}, \mathrm{MgO}, \mathrm{Al}_{2} \mathrm{O}_{3}, \mathrm{MnO}$, and $\mathrm{CaS}$. In the enhanced model, the slag phase also includes a $\mathrm{CaF}_{2}$ component. Typically, $\mathrm{CaF}_{2}$ is included in slag during ladle treatment because $\mathrm{CaF}_{2}$ is able to influence the melting point and viscosity of slag, as well as the desulfurization of molten steel. ${ }^{25)}$ In the enhanced model, for calculating the activities of slag components, including $\mathrm{CaF}_{2}$, the thermodynamic data from Factsage 7.126) were incorporated via Chemapp. ${ }^{27)}$ The activity coefficients of components in the metal phase were calculated using data from the Japan Society for the Promotion of Science. ${ }^{28)}$

\subsection{Generation of $\mathrm{MgAl}_{2} \mathrm{O}_{4}$ and $\mathrm{MgO}$ Inclusions through Reactions between $\mathrm{Al}_{2} \mathrm{O}_{3}$ Inclusions and Mg in Steel}

To simulate the generation of $\mathrm{MgAl}_{2} \mathrm{O}_{4}$ and $\mathrm{MgO}$ inclusions, the compositions of $\mathrm{Al}_{2} \mathrm{O}_{3}$ inclusions were changed based on reactions with the $\mathrm{Mg}$ in steel using a stability diagram $^{29)}$ of $\mathrm{Mg}-\mathrm{Al}-\mathrm{O}$ in steel. First, for the generation of spinel inclusions, the concept of a stability diagram between $[\mathrm{Al}]$ and $[\mathrm{Mg}]$ was applied based on the following equations:

$$
\begin{gathered}
3[\mathrm{Mg}]+4\left(\mathrm{Al}_{2} \mathrm{O}_{3}\right)_{I n c .}=3\left(\mathrm{MgAl}_{2} \mathrm{O}_{4}\right)_{I n c .}+2[\mathrm{Al}] \ldots \ldots . \\
\log \mathrm{K}_{(1)}=34.37-46950 / \mathrm{T} \ldots \ldots \ldots \ldots \ldots . . \\
{[\mathrm{Mg}]^{\text {spinel }}=\left(\frac{1}{\mathrm{~K}_{(1)}} \cdot \frac{a_{\mathrm{MgAl}_{2} \mathrm{O}_{4}}^{3}}{a_{\mathrm{Al} \mathrm{O}_{3}}^{4}} \cdot \frac{f_{[A l]}^{2}}{f_{[M g]}^{3}} \cdot[\mathrm{Al}]^{2}\right)^{1 / 3} \ldots \ldots .}
\end{gathered}
$$

Equation (1) can be converted into Eq. (3) using $[M g]^{\text {spinel }}$, which represents the equilibrated content of [Mg] between $\mathrm{Al}_{2} \mathrm{O}_{3}$ and $\mathrm{MgAl}_{2} \mathrm{O}_{4}$ spinel. In Eq. (3), $K$ is the equilibrium constant calculated using Eq. (2). ${ }^{2)} T$ is the temperature, $a_{i}$ and $f_{i}$ are the activity and activity coefficient of element $i$, respectively. [i] and (i) are the concentrations of element $i$ in the molten steel and slag (or inclusions), respectively.

Figure 2 presents an $\mathrm{Al}-\mathrm{Mg}-\mathrm{O}-$ based stability diagram considering previous results. ${ }^{30}$ ) Regarding the previous results in Fig. 2, the stable state of inclusions transitions into the formation of spinel with increasing reaction time. It is well known that $\mathrm{Al}_{2} \mathrm{O}_{3}$ inclusions are converted into $\mathrm{MgAl}_{2} \mathrm{O}_{4}$ spinel inclusions with increasing $[\mathrm{Mg}]$ content in $\mathrm{Al}_{2} \mathrm{O}_{3}$ inclusions.

Based on the equilibrium state of inclusions with changing steel compositions, the formation of spinel was simulated using the enhanced model. When $[M g]^{\text {bulk }}$ is smaller

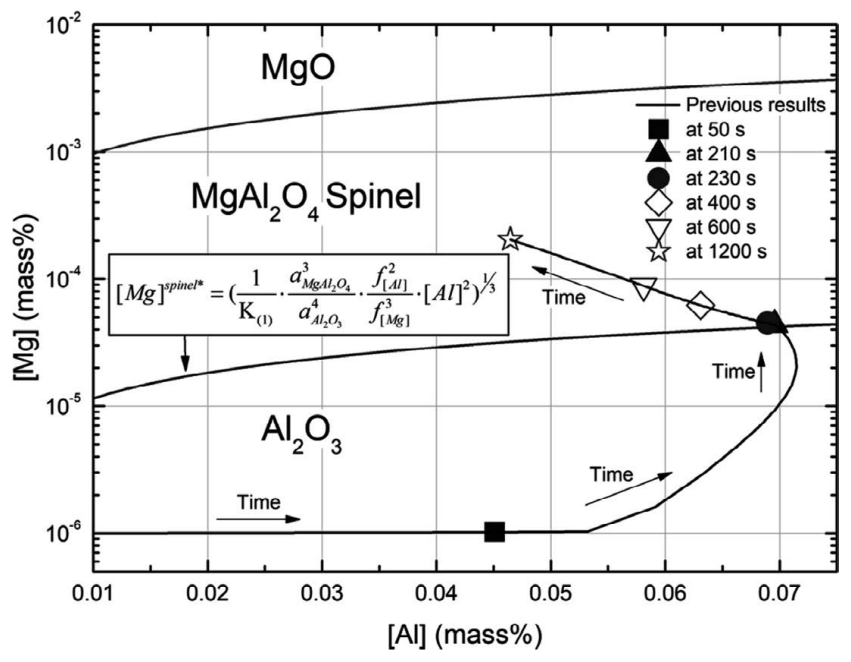

Fig. 2. Stability diagram of a $\mathrm{Mg}-\mathrm{Al}-\mathrm{O}$ system considering previous results.

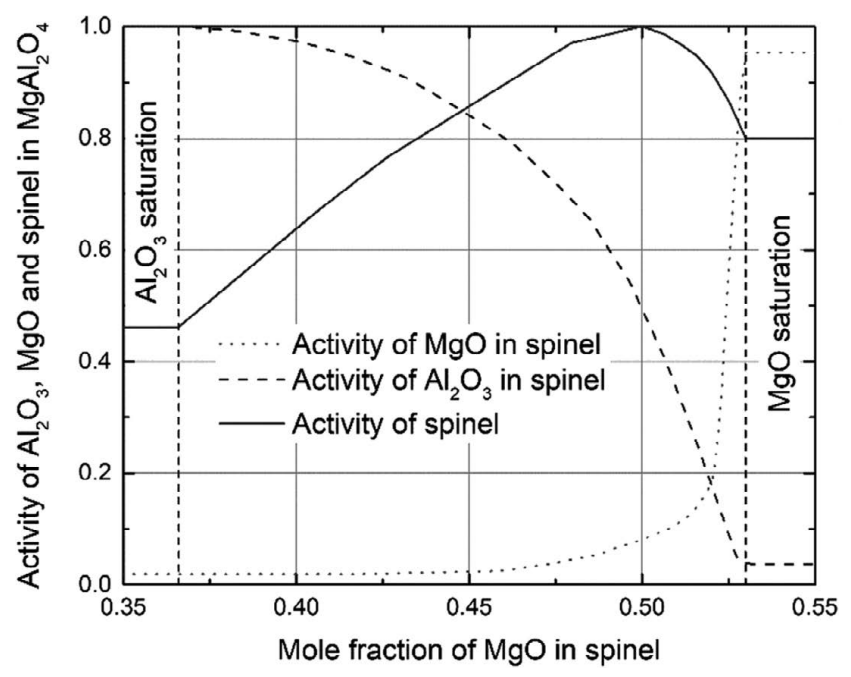

Fig. 3. Activity changes of $\mathrm{Al}_{2} \mathrm{O}_{3}, \mathrm{MgO}$, and spinel in $\mathrm{MgAl}_{2} \mathrm{O}_{4}$ with changing spinel composition.

than $[M g]^{\text {spinel }}$,, $\mathrm{Al}_{2} \mathrm{O}_{3}$ is stable, where $[M g]^{\text {bulk }}$ is the concentration of $\mathrm{Mg}$ in the molten steel. In contrast, when $[M g]^{\text {spinel }}{ }^{*}$ is greater than $[M g]^{\text {bulk }}$, the generation of spinel inclusions begins. Based on Eq. (3), the activities of $\mathrm{Al}_{2} \mathrm{O}_{3}$ and $\mathrm{MgAl}_{2} \mathrm{O}_{4}$ spinel were calculated in the enhanced model using reported data, ${ }^{29)}$ as shown in Fig. 3.

Next, the generation of $\mathrm{MgO}$ inclusions was simulated using the following equations:

$$
\begin{aligned}
& \left(\mathrm{MgAl}_{2} \mathrm{O}_{4}\right)_{I n c .}+3[\mathrm{Mg}]=4(\mathrm{MgO})_{I n c .}+2[\mathrm{Al}] \\
& \log \mathrm{K}_{(4)}=33.09-50880 / T \\
& {[M g]^{M g O \text { sat. }}=\left(\frac{1}{\mathrm{~K}_{(4)}} \cdot \frac{a_{\mathrm{MgO}^{2} \mathrm{O}}^{4}}{a_{\mathrm{MgAl}_{2} \mathrm{O}_{4}}} \cdot \frac{f_{[A l]}^{2}}{f_{[M g]}^{3}} \cdot[A l]^{2}\right)^{1 / 3} .}
\end{aligned}
$$

Equation (4) represents the generation of $\mathrm{MgO}$ inclusions from spinel, and can be transformed into Eq. (6) using the activity terms and equilibrium constant $K_{(4)}{ }^{2)}$ Based on Eq. (6), the equilibrium concentration of $\mathrm{Mg}$ in the steel between spinel and $\mathrm{MgO}$, denoted $[\mathrm{Mg}]^{\mathrm{MgO} \text { sat. }}$, can be calculated in the enhanced model. Consequently, $\mathrm{MgO}$ inclusions 
are generated when $[\mathrm{Mg}]^{\text {bulk }}$ is greater than $[\mathrm{Mg}]^{\mathrm{MgO} \text { sat. }}$.

Fujii et al. ${ }^{29)}$ investigated the activity changes in spinel with varying spinel compositions. Figure 3 presents the activity changes in $\mathrm{Al}_{2} \mathrm{O}_{3}, \mathrm{MgO}$, and spinel with compositional changes in $\mathrm{MgAl}_{2} \mathrm{O}_{4}$ spinel. ${ }^{29)}$ In Eq. (3), $[M g]^{\text {spinel }}{ }^{*}$ is affected by each activity in spinel. In previous models, the generation of spinel was simulated when the mole fraction of $\mathrm{MgO}$ and $\mathrm{Al}_{2} \mathrm{O}_{3}$ in the spinel was halved and the activity in the spinel was fixed. ${ }^{12-22)}$ However, in the proposed enhanced model, the activities of $\mathrm{Al}_{2} \mathrm{O}_{3}, \mathrm{MgO}$, and spinel change with increasing $\mathrm{MgO}$ content in $\mathrm{Mg}-\mathrm{Al}$-based inclusions.

Compositional changes in spinel were simulated using the following equation.

$$
\frac{d[M g]^{\mathrm{Mg}-\mathrm{Al} \text { inc. }}}{d t}=k_{[M g]}^{\text {spinel }} \cdot \frac{A}{V} \cdot\left([M g]^{b u l k}-[M g]^{e q^{*}}\right) \cdot \frac{N_{M g O}}{N_{M g}} \ldots
$$

where $[M g]^{M g-A l ~ i n c . ~ i s ~ t h e ~ c o n c e n t r a t i o n ~ o f ~} \mathrm{Mg}$ in $\mathrm{Mg}-\mathrm{Al}-$ based inclusions, $t$ is the time (s), $k_{[M g]}$ spinel is the mass transfer coefficient of $\mathrm{Mg}$ into spinel $(\mathrm{m} / \mathrm{s}), A$ is the total interfacial area between inclusions and molten steel $\left(\mathrm{m}^{2}\right)$, $V$ is the volume of molten steel $\left(\mathrm{m}^{3}\right)$, and $N_{i}$ is the molar weight of species $i$. The mass transfer coefficient of $\mathrm{Mg}$ into $\mathrm{Mg}-\mathrm{Al}$-based inclusions was assumed to equal $k_{[\mathrm{Mg}]}$ spinel. $A$ is calculated as (number of inclusions) $\times$ (area of inclusions). In this study, the average diameter of a single $\mathrm{Al}_{2} \mathrm{O}_{3}$ inclusion was assumed to be $10 \mu \mathrm{m}$. $[\mathrm{Mg}]^{\text {bulk }}$ and $[\mathrm{Mg}]^{e q^{*}}$ can be calculated using the double-film theory with Eqs. (3) and (6), respectively. $[M g]^{e q^{*}}$ is determined based on the inclusion stable state in the stability diagram of $\mathrm{Mg}-\mathrm{Al}-\mathrm{O}$. For example, Eq. (3) is equal to $[M g]^{e q^{*}}$ when the spinel inclusions are stable. Eq. (6) is used for the stable state of $\mathrm{MgO}$ inclusions. The mass transfer coefficient of $\mathrm{Mg}$ into spinel $\left.\left(k_{[M g}\right]^{\text {spinel }}\right)$ can be calculated as follows: $:^{31)}$

$$
k_{[M g]}^{\text {spinel }}=\frac{S h \cdot D_{(M g O)}^{\text {spinel }}}{d}
$$

where $D_{(M g O)}{ }^{\text {spinel }}$ represents the diffusivity of $\mathrm{MgO}$ into spinel $\left(\mathrm{m}^{2} / \mathrm{s}\right)$ based on reported data. ${ }^{11)} d$ is the average diameter of inclusions (m). In Eq. (9), $S h$ is the Sherwood number, ${ }^{32)}$ which can be obtained from the Reynolds number and Schmidt number as follows:

$$
\begin{aligned}
& S h=2+0.6 \cdot \operatorname{Re}^{1 / 2} \cdot S c^{1 / 3}, 0 \leq \operatorname{Re}<200,0 \leq S c<250 \ldots \ldots \\
& \operatorname{Re}=\frac{\rho u L}{\mu} \\
& S c=\frac{\mu}{\rho D}
\end{aligned}
$$

The Reynolds number $(R e)$ and Schmidt number $(S c)$ are defined by Eqs. (10) and (11), respectively. $\rho, u$, and $\mu$ are the density $\left(\mathrm{kg} / \mathrm{m}^{3}\right)$, slip velocity $(\mathrm{m} / \mathrm{s})$, and dynamic viscosity $\left(\mathrm{N} \cdot \mathrm{s} / \mathrm{m}^{2}\right)$ of the molten steel, respectively. $L$ is the average diameter of inclusions (m) and $D$ is the diffusivity of $\mathrm{Mg}$ in molten steel $\left(\mathrm{m}^{2} / \mathrm{s}\right)$. The slip velocity of molten steel can be calculated by the enhanced model. ${ }^{20)}$ The dynamic viscosity of the molten steel was calculated using a standard viscosity formula. ${ }^{33)}$ Using Eqs. (7) to (11), the

\begin{tabular}{|c|c|}
\hline Mass of steel and slag & Steel: 210 ton, Slag: 2.5 ton \\
\hline $\begin{array}{l}\text { Initial composition of steel } \\
\text { (before 2nd de-oxidation reaction) }\end{array}$ & $\begin{array}{l}\text { C: } 0.11 \% \text {; Mn: } 0.90 \% \text {; Cr: } 0.24 \% \text {; } \\
\text { Si: } 0.38 \% \text {; Al: } 0.01 \% \text {; O: } 13 \text { ppm }\end{array}$ \\
\hline $\begin{array}{l}\text { Initial composition of slag } \\
\text { (before } 2 \text { nd de-oxidation reaction) }\end{array}$ & $\begin{array}{c}\mathrm{CaO}: 54 \% ; \mathrm{SiO}_{2}: 12 \% ; \mathrm{Al}_{2} \mathrm{O}_{3}: \\
\text { 22\%; } \mathrm{MgO}: 8 \% ; \mathrm{MnO}^{\circ} 0.5 \% ; \mathrm{FeO}: \\
\text { 0.5\%; } \mathrm{CaF}_{2}: 4 \%\end{array}$ \\
\hline De-oxidation alloying & Al 0.13 ton at $10 \mathrm{~s}$ \\
\hline Gas flow rate (recirculation) & Ar soft blowing, $133 \mathrm{Nl} / \mathrm{min}$ \\
\hline Temperature $\left({ }^{\circ} \mathrm{C}\right)$ & 1600 \\
\hline $\begin{array}{l}\text { Mass transfer coefficient ratio } \\
\text { (Metal/Slag) }\end{array}$ & 2 \\
\hline Area of furnace $\left(\mathrm{cm}^{2}\right)$ & 80384 \\
\hline Calculation step (sec) & 2 \\
\hline Calculation time (sec) & 1200 \\
\hline
\end{tabular}
compositional changes in $\mathrm{Mg}-\mathrm{Al}$-based inclusions can be calculated by the enhanced model.
Table 1. Calculation conditions at the initial state based on industrial data for a 210 -ton sample.

\subsection{Calculation Conditions}

Table 1 lists the calculation conditions at the initial state based on industrial data ${ }^{13)}$ for a 210-ton sample. Inclusion behavior parameters were set to optimized values based on our previous work by comparing the total composition changes of inclusions in the ICS model to those of inclusions in our current results. ${ }^{30)}$ In our previous work, we investigated the effects of inclusion behavior parameters on overall compositional changes and the number of inclusions.

\section{Results \& Discussion}

\subsection{Compositional Changes in $\mathrm{MgAl}_{2} \mathrm{O}_{4}$ Spinel Inclu- sions}

Figures $\mathbf{4}$ and $\mathbf{5}$ present the results of model reliability based on compositional changes in the molten steel and slag. In Fig. 4(a), the Al content in the steel increases to $0.07 \%$ at the start of calculation, then decreases based on de-oxidation. In Fig. 4(b), the concentration of $\mathrm{O}$ decreases based on $\mathrm{Al}$ de-oxidation. Both results are in good agreement with measured results at $1200 \mathrm{~s}$. In Fig. 5, the compositions of $\mathrm{CaO}, \mathrm{Al}_{2} \mathrm{O}_{3}, \mathrm{SiO}_{2}$, and $\mathrm{MgO}$ in slag are compared between the ICS model, ${ }^{13,14)}$ enhanced model, and measured results. The enhanced model shows closer agreement with the measured results at $1200 \mathrm{~s}$.

Figure 6 presents the concentration changes of $[M g]^{b u l k}$, $[M g]^{\text {spinel }^{*}}$, and $[\mathrm{Mg}]^{\mathrm{MgO} \text { sat. }}$ in steel. For the previous model, after $210 \mathrm{~s}$, spinel inclusions are formed when the Gibbs free energy of the spinel inclusions is stable. Therefore, after 210 $\mathrm{s}$, the growth of $[M g]^{\text {bulk }}$ slows based on spinel generation. Regarding the results of the enhanced model, the spinel becomes the stable after $150 \mathrm{~s}$ because $[M g]^{\text {bulk }}$ is close to $[M g]^{\text {spinel }}{ }^{*} .[M g]^{\text {bulk }}$ is greater than $[M g]^{\text {spinel }^{*}}$ after $310 \mathrm{~s}$. The reason for the decrease in $[M g]^{\text {bulk }}$ between $150 \mathrm{~s}$ and $310 \mathrm{~s}$ is that the $\mathrm{Mg}$ in steel transforms into $\mathrm{MgO}$ content in $\mathrm{Al}_{2} \mathrm{O}_{3}$ inclusions based on Eq. (7). However, $[M g]^{M g O ~ s a t . ~}$ is much greater than $[\mathrm{Mg}]^{\text {bulk }}$ at the right-side y axis. Figures 7 and 8 present compositional changes in $\mathrm{Al}_{2} \mathrm{O}_{3}$ and spinel inclusions, and a phase diagram ${ }^{34)}$ of $\mathrm{Al}_{2} \mathrm{O}_{3}$ and $\mathrm{MgO}$, respectively. In Fig. 7, one can see that the $\mathrm{MgO}$ content 

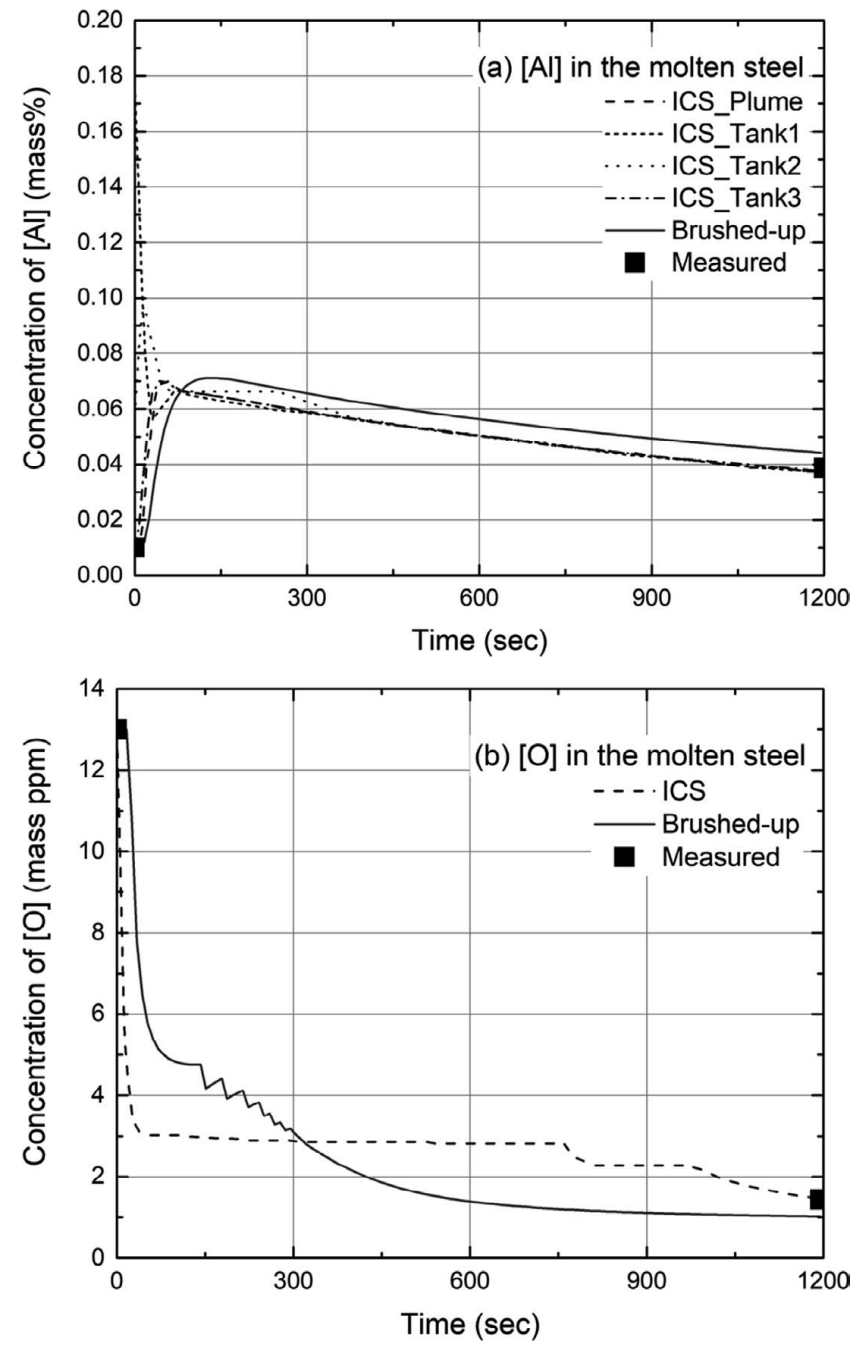

Fig. 4. Concentration changes of $[\mathrm{Al}](\mathrm{a})$ and $[\mathrm{O}](\mathrm{b})$ in the molten steel.

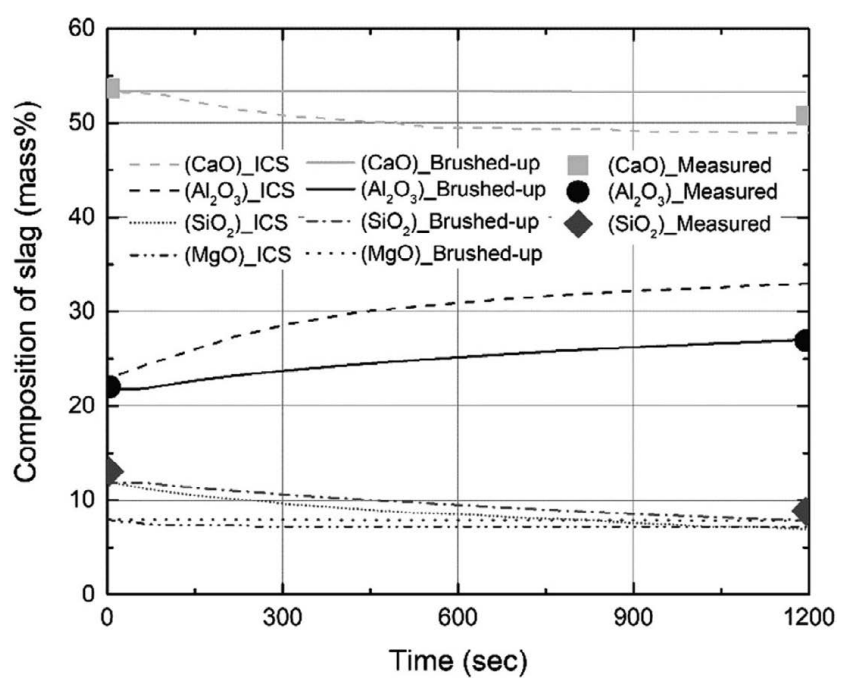

Fig. 5. Compositional changes of $\mathrm{CaO}, \mathrm{Al}_{2} \mathrm{O}_{3}, \mathrm{SiO}_{2}$, and $\mathrm{MgO}$ in the slag.

in $\mathrm{Al}_{2} \mathrm{O}_{3}$ inclusions increases significantly with increasing $[\mathrm{Mg}]^{\text {bulk }}$ up to $150 \mathrm{~s}$, reaching a level of $18 \mathrm{mass} \%$ at 150 $\mathrm{s}$. The composition of $\mathrm{Mg}-\mathrm{Al}$-based inclusions at $150 \mathrm{~s}$ is close to the equilibrium composition between $\mathrm{Al}_{2} \mathrm{O}_{3}$ and

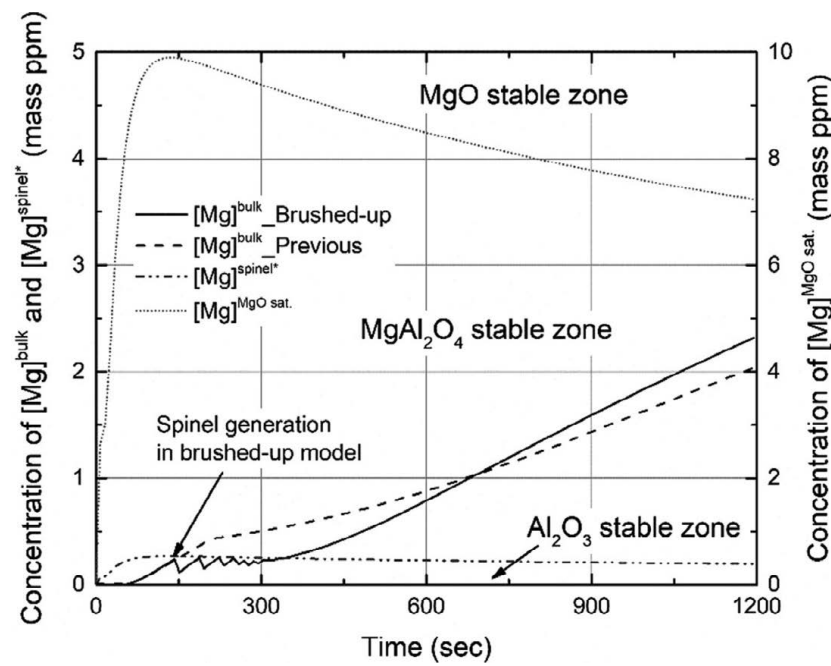

Fig. 6. Concentration changes in $[M g]^{\text {bulk }},[M g]^{\text {spinel }}$, and $[M g]^{M g O \text { sat. }}$. from previous results to enhanced results.

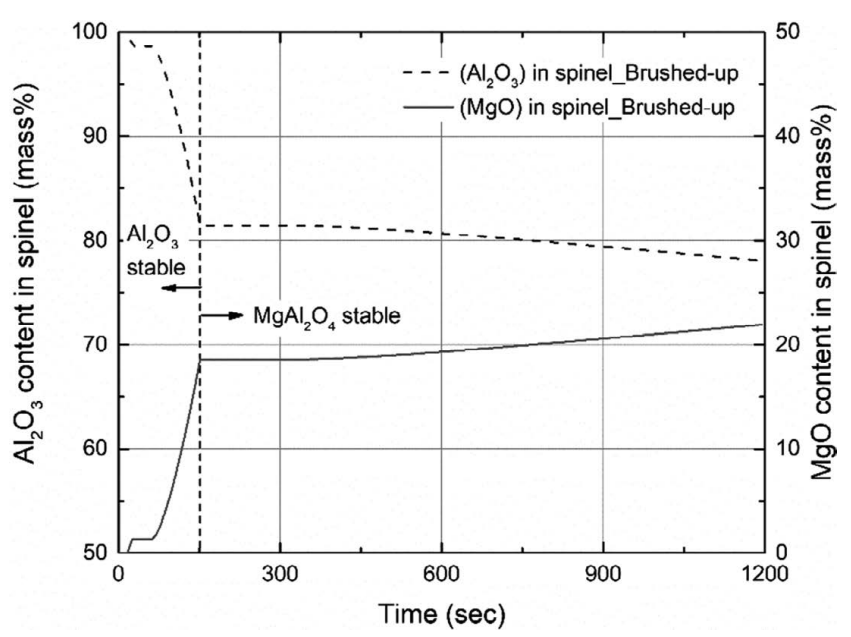

Fig. 7. Compositional changes of $\mathrm{Al}_{2} \mathrm{O}_{3}$ and $\mathrm{MgO}$ in $\mathrm{Mg}-\mathrm{Al}-$ based inclusions.

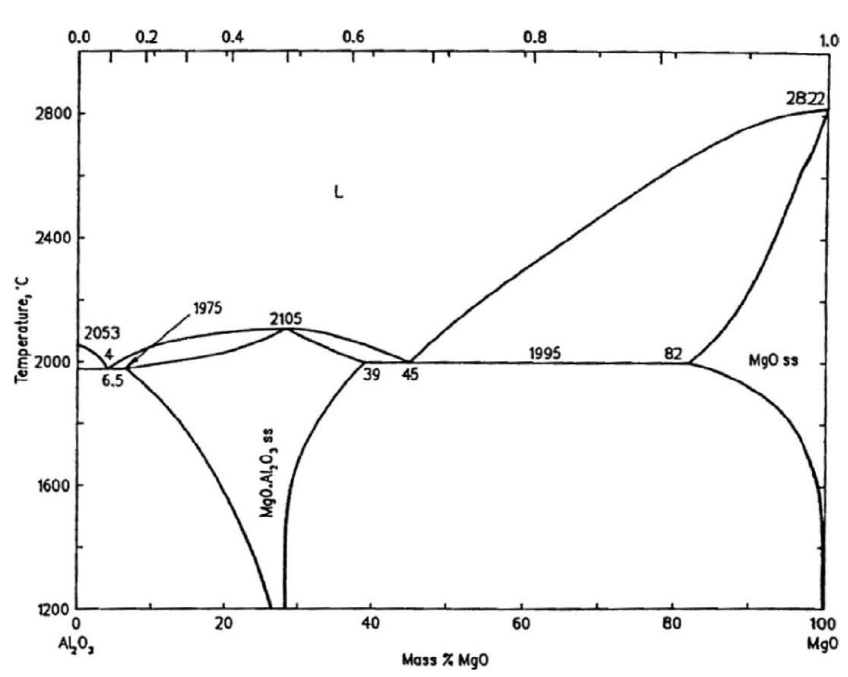

Fig. 8. Phase diagram of an $\mathrm{Al}_{2} \mathrm{O}_{3}$ and $\mathrm{MgO}$ system. ${ }^{30}$ )

$\mathrm{MgAl}_{2} \mathrm{O}_{4}$ spinel in the phase diagram, as shown in Fig. 8. ${ }^{34)}$ Therefore, the kinetic model accurately simulated spinel generation according to the phase diagram. After $150 \mathrm{~s}$, spinel inclusions are generated and a decreasing gradient of 
$\mathrm{MgO}$ content is caused by the difference driving force of the spinel inclusion in Eq. (3). Additionally, in Fig. 8, when the $\mathrm{MgO}$ content in the $\mathrm{MgO}-\mathrm{Al}_{2} \mathrm{O}_{3}$ system is greater than 18 mass $\%$, the spinel is stable. Following spinel generation, the $\mathrm{MgO}$ content in the spinel inclusions gradually increases up to 22 mass \% at $1200 \mathrm{~s}$. However, the $\mathrm{MgO}$ content in $\mathrm{MgO}$ generation is much greater than the $\mathrm{MgO}$ content of spinel inclusions. Furthermore, if $[M g]^{b u l k}$ increases further, spinel inclusions can evolve into $\mathrm{MgO}$-rich inclusions.

Figures 9 and $\mathbf{1 0}$ present the compositional changes in all inclusions. In Fig. 9, the $\mathrm{MgO}$ content in the enhanced results decreases compared to the previous results. The mole fraction of $\mathrm{MgO}$ in the spinel inclusions is assumed to be halved in the previous results, so its value is much larger than the enhanced results. Figure 10 presents a ternary phase diagram of a $\mathrm{CaO}-\mathrm{MgO}-\mathrm{Al}_{2} \mathrm{O}_{3}$ system based on our calculation results. The increase in $\mathrm{CaO}$ content in the inclusions is influenced by the inclusions originating from slag. However, when considering the curved line in the ternary phase diagram, one can see that the calculation results bend significantly following Ca-treatment. It is well known that spinel is a very harmful inclusion based on its

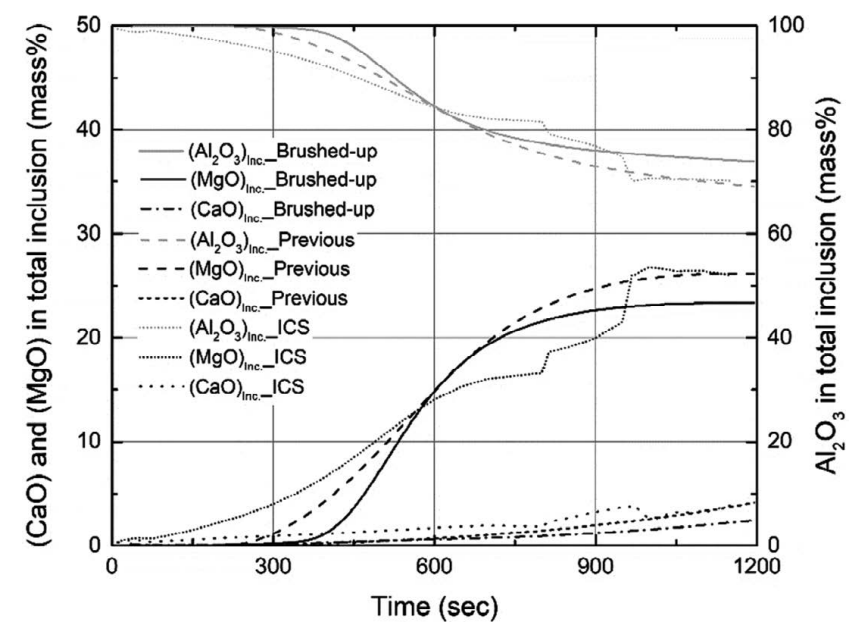

Fig. 9. Compositional changes of $\mathrm{Al}_{2} \mathrm{O}_{3}, \mathrm{MgO}$, and $\mathrm{CaO}$ in total inclusions.

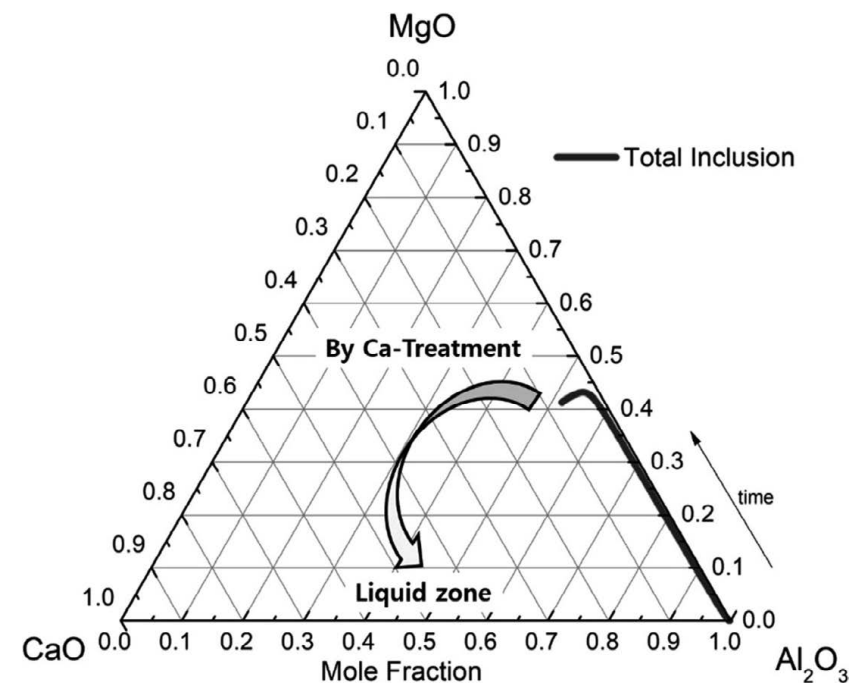

Fig. 10. Ternary phase diagram of an $\mathrm{Al}_{2} \mathrm{O}_{3}-\mathrm{MgO}-\mathrm{CaO}$ system based on calculation results. low deformation and high melting point. The purpose of inclusion control is to generate softer inclusions, such as liquid calcium-aluminate.

Figure 11 presents the changes in $\mathrm{Al}_{2} \mathrm{O}_{3}$ inclusion and spinel inclusion content. The amount of $\mathrm{Al}_{2} \mathrm{O}_{3}$ is the same between the previous results and enhanced results because the method of forming $\mathrm{Al}_{2} \mathrm{O}_{3}$ inclusions did not changed between the previous model and enhanced model. However, the amount of spinel inclusion in the enhanced results is decreased compared to the previous results. In the previous model, the activity of $\mathrm{MgO}$ in spinel inclusions was fixed as 0.8 with a halved mole fraction. The activity value for the enhanced model is much smaller than that for the previous model, as shown in Fig. 3. In the enhanced results, spinel inclusions form after $150 \mathrm{~s}$ when $[M g]^{\text {bulk }}$ is close to $[M g]^{\text {spinel }^{*}}$. The content increases significantly after $310 \mathrm{~s}$ based on the increasing value of $[M g]^{\text {bulk }}$ in Fig. 6. The local maximum amount of spinel inclusions is approximately 10 $\mathrm{kg}$ at $580 \mathrm{~s}$. Then the amount decreases gradually based on the flotation of inclusions into the slag phase.

\subsection{Influence of Slag Composition}

Many previous studies have contained experiments to clarify the influence of the $\mathrm{CaO} / \mathrm{SiO}_{2}$ ratio in slag on spinel generation, as referenced in Section 1. These studies discovered that when the $\mathrm{CaO} / \mathrm{SiO}_{2}$ ratio in slag increases, the $\mathrm{MgO}$ content in $\mathrm{Al}_{2} \mathrm{O}_{3}$ inclusions increases and the diffusivity rate of $\mathrm{Mg}$ in steel increases. ${ }^{4-6)}$ These results indicate that the generation of spinel inclusions can be suppressed by a low $\mathrm{CaO} / \mathrm{SiO}_{2}$ ratio in slag. Therefore, the influence of the initial $\mathrm{CaO} / \mathrm{SiO}_{2}$ ratio in slag on the generation of spinel inclusions was evaluated using the enhanced model, as shown in Fig. 12. The $\mathrm{CaO} / \mathrm{SiO}_{2}$ ratio in slag was varied in the range of 2-4.5. When the $\mathrm{CaO} / \mathrm{SiO}_{2}$ ratio in slag decreases, the local maximum amount of spinel inclusions decreases and the initiation time of spinel generation is delayed. To investigate the influence of the $\mathrm{CaO} / \mathrm{SiO}_{2}$ ratio in slag, the equilibrium distribution ratio of $\mathrm{Mg}$ between the reactions of $\mathrm{Mg} / \mathrm{MgO}$ and $\mathrm{Al} / \mathrm{Al}_{2} \mathrm{O}_{3}$ was calculated as follows:

$$
3(\mathrm{MgO})+2[\mathrm{Al}]=3[\mathrm{Mg}]+\left(\mathrm{Al}_{2} \mathrm{O}_{3}\right)
$$

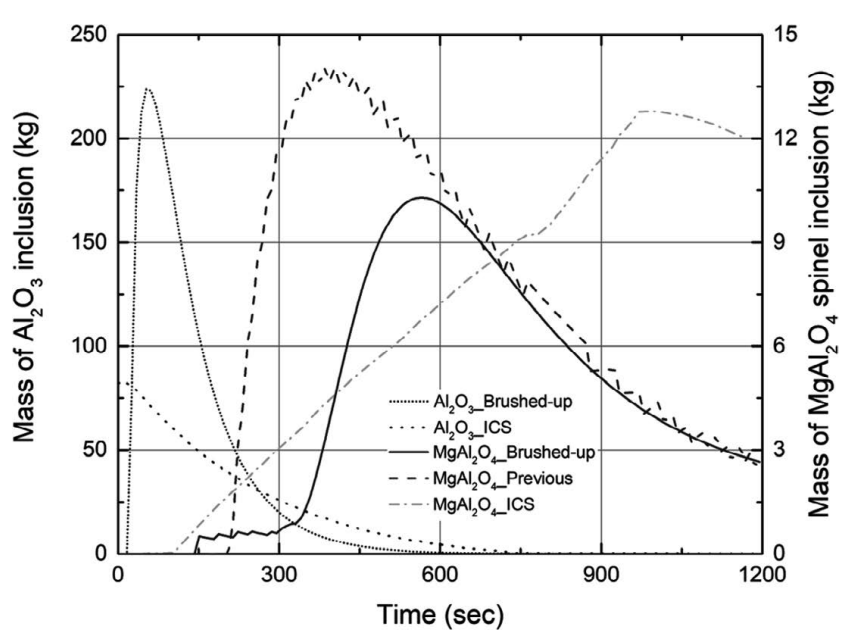

Fig. 11. Content changes for $\mathrm{Al}_{2} \mathrm{O}_{3}$ inclusions and $\mathrm{MgAl}_{2} \mathrm{O}_{4}$ spinel inclusions between the enhanced model, previous model, and ICS model. 
$\log \mathrm{K}_{(12)}=-24.46+31200 / T$

$$
L_{M g}=\frac{(M g O \%)}{[M g \%]}=\frac{1}{K_{(12)}^{1 / 3}} \cdot \frac{f_{[M g]}}{\gamma_{(M g O)}} \cdot \frac{a_{\left(\mathrm{Al}_{2} \mathrm{O}_{3}\right)}^{1 / 3}}{a_{[\mathrm{Al}]}^{2 / 3}} \cdot \mathrm{N}_{\mathrm{MgO}} \cdots
$$

Equation (12) can be converted into Eq. (14) to derive $L_{M g}$, which denotes the equilibrium distribution ratio of $\mathrm{Mg}$. The equilibrium constant $K_{(12)}$ in Eq. (14) is calculated using Eq. (13). ${ }^{28)}$ Figure 13 illustrates the value of $L_{M g}$ and ratio of $f_{M g} / \gamma_{M g O}$ calculated using Eq. (14). The ratio of $f_{M g} / \gamma_{M g O}$ is almost constant as the $\mathrm{CaO} / \mathrm{SiO}_{2}$ ratio in slag changes, but the activities of $\mathrm{Al}$ in steel and $\mathrm{Al}_{2} \mathrm{O}_{3}$ in slag become dominant parameters for the value of $L_{M g}$. When the $\mathrm{CaO} /$ $\mathrm{SiO}_{2}$ ratio decreases, the value of $L_{M g}$ increases. This indicates that the $\mathrm{CaO} / \mathrm{SiO}_{2}$ ratio in slag influences the activity of $\mathrm{Al}_{2} \mathrm{O}_{3}$ in Eq. (14). Additionally, the component of $\mathrm{MgO}$ in slag at a higher value of $L_{M g}$ is much more stable than that at a lower value (i.e., the reduction tendency of $\mathrm{MgO}$ in slag decreases at a higher value of $L_{M g}$ ). Therefore, $[M g]^{\text {bulk }}$ decreases with a lower $\mathrm{CaO} / \mathrm{SiO}_{2}$ ratio in slag based on a higher value of $L_{M g}$. The $\mathrm{Mg}$ content in steel is related to the driving force of spinel generation based on Eq. (7).

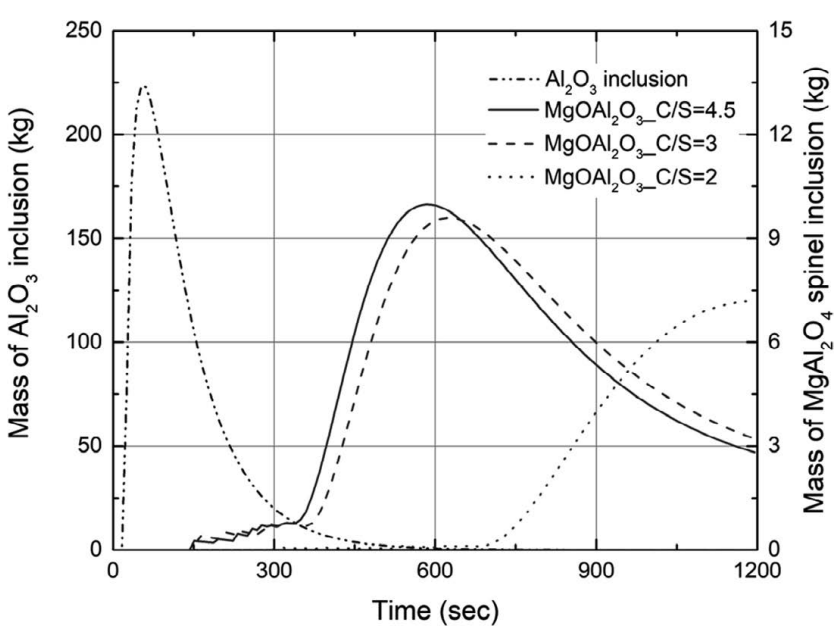

Fig. 12. Content changes of $\mathrm{Al}_{2} \mathrm{O}_{3}$ inclusions and $\mathrm{MgAl}_{2} \mathrm{O}_{4}$ spinel inclusions with variations of the $\mathrm{CaO} / \mathrm{SiO}_{2}$ ratio in slag (2 to 4.5 ).

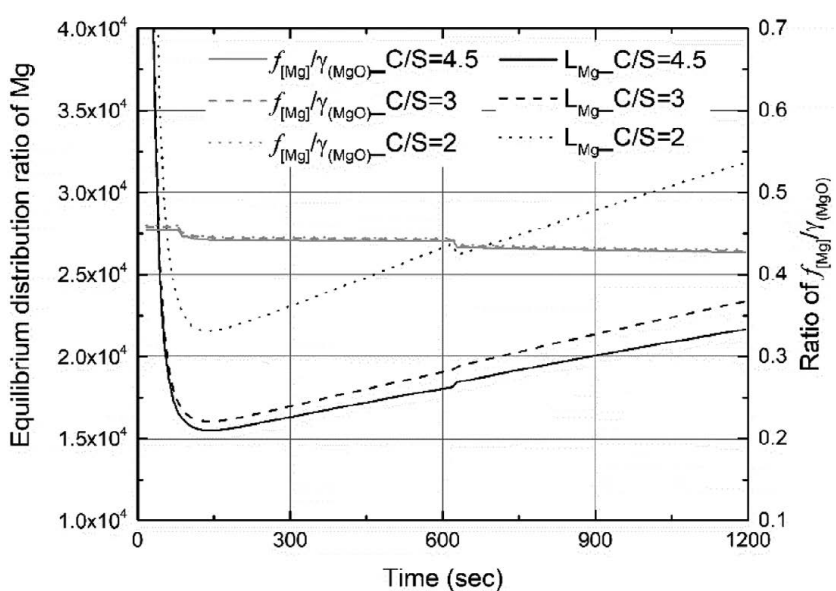

Fig. 13. Equilibrium distribution ratio of $\mathrm{Mg}$, and the ratio of $f_{M g} /$ $\gamma_{\mathrm{MgO}}$ in Eq. (14) by variation of the $\mathrm{CaO} / \mathrm{SiO}_{2}$ ratio in slag (2 to 4.5$)$.
Therefore, the driving force of spinel generation decreases at a lower $\mathrm{CaO} / \mathrm{SiO}_{2}$ ratio in slag. These calculation results show good agreement with previous experimental results. ${ }^{4-6)}$ Therefore, we can conclude that when the $\mathrm{CaO} / \mathrm{SiO}_{2}$ ratio in slag decreases, the local maximum amount and initiation time of spinel generation decrease based on a greater value of $L_{M g}$.

\subsection{Evolution of $\mathrm{MgAl}_{2} \mathrm{O}_{4}$ Spinel Inclusions into $\mathrm{MgO}$ Inclusions}

Typically, the Mg content in molten steel increases during ladle treatment without the addition of $\mathrm{Mg}$ based on the reduction of $\mathrm{MgO}$ in slag and dissolution of refractorybased $\mathrm{MgO}$. Therefore, in Fig. 6, if $[M g]^{\text {bulk }}$ is greater than $[\mathrm{Mg}]^{\mathrm{MgO} \text { sat. }}$, then $\mathrm{MgO}$-rich inclusions can be generated from spinel inclusions. To simulate the generation of $\mathrm{MgO}$ rich inclusions, the calculation time set to $7200 \mathrm{~s}$ for the enhanced model. Figure $\mathbf{1 4}$ presents the concentration changes of $[\mathrm{Mg}]$ in the molten steel. $[M g]^{b u l k}$ exceeds than $[\mathrm{Mg}]^{\mathrm{MgO} \text { sat. }}$ after $3680 \mathrm{~s}$. Therefore, MgO-rich inclusions become thermodynamically stable state after 3680 s. In Fig. 15, one can see that the $\mathrm{MgO}$ content in $\mathrm{Mg}-\mathrm{Al}$-based inclu-

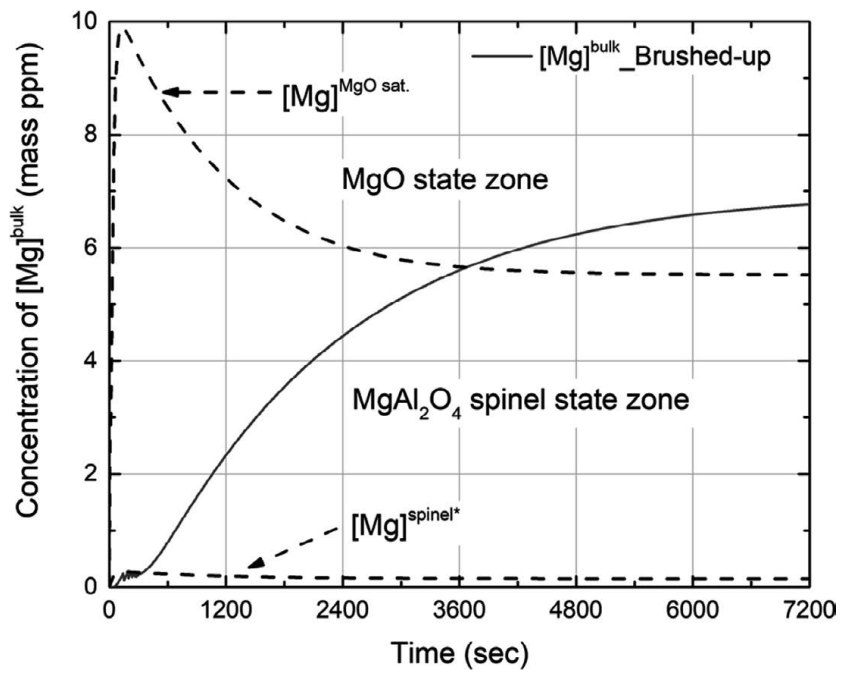

Fig. 14. Concentration changes of $[M g]^{\text {bulk }}$ over $7200 \mathrm{~s}$.

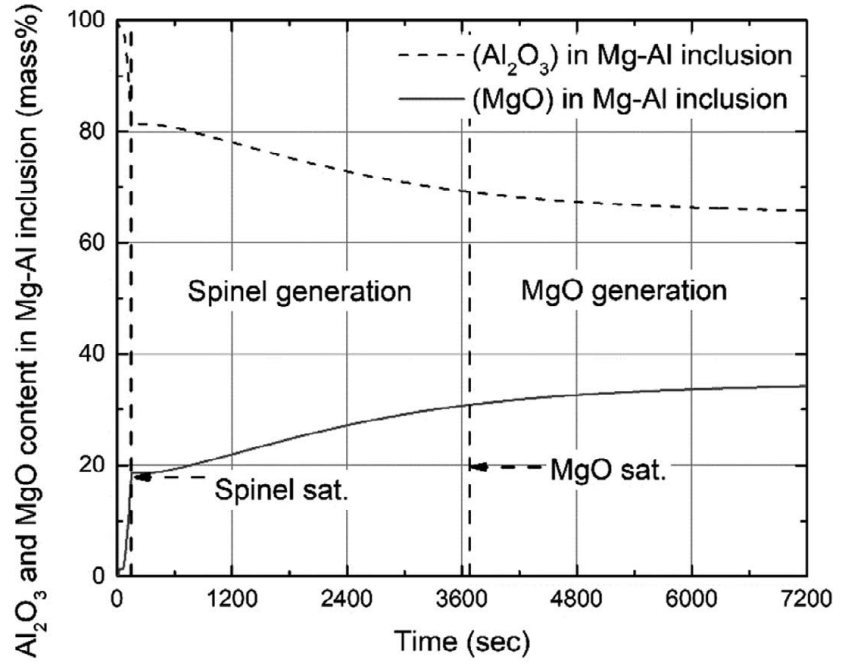

Fig. 15. Compositional changes of $\mathrm{Al}_{2} \mathrm{O}_{3}$ and $\mathrm{MgO}$ in $\mathrm{Mg}-\mathrm{Al}-$ based inclusions over $7200 \mathrm{~s}$. 


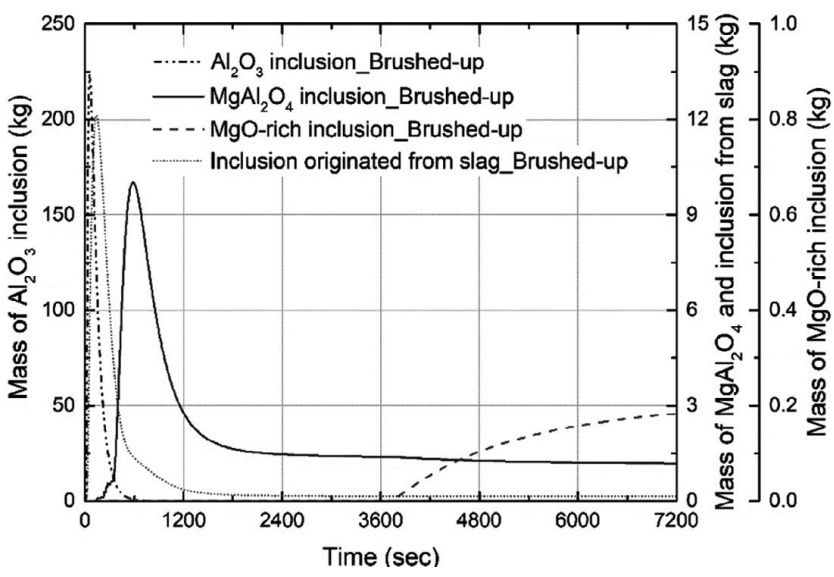

Fig. 16. Content changes of $\mathrm{Al}_{2} \mathrm{O}_{3}, \mathrm{MgAl}_{2} \mathrm{O}_{4}$ spinel, $\mathrm{MgO}$-rich inclusions, as well as the inclusions originating from slag.

sions is 30.8 mass $\%$ at $3680 \mathrm{~s}$, indicating compositional changes in $\mathrm{Mg}-\mathrm{Al}$-based inclusions. The $\mathrm{MgO}$ content nears the equilibrium composition between $\mathrm{MgO}$ and $\mathrm{MgAl}_{2} \mathrm{O}_{4}$ spinel in Fig. 8, which presents a phase diagram of $\mathrm{MgO}_{-}$ $\mathrm{Al}_{2} \mathrm{O}_{3}$ system. Figure 16 presents the content changes of $\mathrm{Mg}-\mathrm{Al}$-based inclusions and inclusions originating from slag. A small amount of MgO-rich inclusions is generated after $3680 \mathrm{~s}$. However, after $3680 \mathrm{sec}$, the decreasing trend in spinel inclusions is similar to the increasing trend in $\mathrm{MgO}$-rich inclusions. The flotation of inclusions into slag is considered in the enhanced model, but flotation rarely occurs after $3000 \mathrm{~s}$, as shown by the content changes of the inclusions. This indicates that $\mathrm{MgO}$-rich inclusions were evolved from spinel inclusions with increasing $\mathrm{MgO}$ content in $\mathrm{Mg}$-Al-based inclusions. MgO-rich inclusions have been observed in previous studies. ${ }^{7,8)}$ Therefore, proposed kinetic model can accurately model the inclusion evolution from $\mathrm{Al}_{2} \mathrm{O}_{3}$ inclusions to $\mathrm{MgO}$-rich inclusions and the associated changes in composition.

\section{Conclusion}

In this study, we enhanced an existing kinetic model to predict the compositional changes of molten steel, slag, and inclusions during ladle treatment.

(1) We discussed how to apply the compositional changes in $\mathrm{Mg}-\mathrm{Al}$-based inclusions by considering stability diagrams and activity changes.

(2) The enhanced kinetic model provides reliable predictions of compositional changes in molten steel, slag, and inclusions using industrial data from a 210-ton sample.

(3) When the $\mathrm{CaO} / \mathrm{SiO}_{2}$ ratio in slag decreases, the local maximum amount of $\mathrm{MgAl}_{2} \mathrm{O}_{4}$ spinel inclusions and the initiation time of spinel generation decrease based on a greater equilibrium partition ratio of $\mathrm{Mg}$. Therefore, $\mathrm{Mg}$ content in molten steel is the dominant factor for spinel generation.

(4) $\mathrm{MgAl}_{2} \mathrm{O}_{4}$ spinel inclusions can evolve into $\mathrm{MgO}$ rich inclusions with a gradual increase in $\mathrm{MgO}$ content in $\mathrm{Mg}-\mathrm{Al}$-based inclusions supplied by molten steel.

\section{Acknowledgments}

The authors would like to thank Prof. Shin-ya Kitamura in Tohoku University for his valuable comments about the kinetic reaction and thermodynamics. We appreciate the financial support by the Iron \& Steel Institute of Japan (ISIJ) from the research group on "Refining of Cr Steel by slag and inclusion control". This work was supported by the Korea Institute of Energy Technology Evaluation and Planning and the Ministry of Trade, Industry, \& Energy of the Republic of Korea (No. 20185210100030).

\section{REFERENCES}

1) J. H. Park and Y. Kang: Steel Res. Int., 88 (2017), 1700130.

2) J. H. Park and H. Todoroki: ISIJ Int., 50 (2010), 1333.

3) H. Todoroki, F. Kirihara, Y. Kanbe and Y. Miyazaki: Tetsu-toHagané, 100 (2014), 539 (in Japanese).

4) T. Nishi and K. Shinme: Tetsu-to-Hagané, 84 (1998), 837 (in Japanese).

5) G. Okuyama, K. Yamaguchi, S. Takeuchi and K. Sorimachi: ISIJ Int., 40 (2000), 121.

6) A. Harada, A. Matsui, S. Nabeshima, N. Kikuchi and Y. Miki: ISIJ Int., 57 (2017), 1546.

7) J. H. Park and D. S. Kim: Metall. Mater. Trans. B, 36 (2005), 495.

8) H. Todoroki and K. Mizuno: Iron Steelmaker, 30 (2003), No. 3, 60.

9) A. Harada, G. Miyano, N. Maruoka, H. Shibata and S. Kitamura: ISIJ Int., 54 (2014), 2230.

10) C. Liu, F. Huang and X. Wang: Metall. Mater. Trans. B, 47 (2016), 999.

11) C. Liu, M. Yagi, X. Gao, S.-J. Kim, F. Huang, S. Ueda and S. Kitamura: Metall. Mater. Trans. B, 49 (2018), 113.

12) J. Peter, K. D. Peaslee, D. G. C. Robertson and B. G. Thomas: Proc. Iron \& Steel Technology Conf. (AISTech 2005), Vol. 1, AISTech, Charlotte, (2005), 959.

13) Q. Shu, O. Volkova, S. Lachmann and P. R. Scheller: Proc. Iron \& Steel Technology Conf. (AISTech 2011), Vol. 2, AISTech, Indianapolis, (2011), 537.

14) T. Dubberstein, O. Volkova, S. Lachmann and P. R. Scheller: Proc. Int. Conf. on Clean Steel, OMBKE, Budapest, (2012), 1.

15) M.-A. Van Ende and I.-H. Jung: Metall. Mater. Trans. B, 48 (2017), 28.

16) Y. Ren, Y. Zhang and L. Zhang: Ironmaking Steelmaking, 44 (2017), 497.

17) Y. Ren, L. Zhang, H. Ling, Y. Wang, D. Pan, Q. Ren and X. Wang: Metall. Mater. Trans. B, 48 (2017), 1433.

18) Y. Ren and L. Zhang: Ironmaking Steelmaking, 45 (2018), 585.

19) Y. Ren, L. Zhang and Y. Zhang: J. Iron Steel Res. Int., 25 (2018), 146.

20) A. Harada, N. Maruoka, H. Shibata and S. Kitamura: ISIJ Int., 53 (2013), 2110.

21) A. Harada, N. Maruoka, H. Shibata and S. Kitamura: ISIJ Int., 53 (2013), 2118.

22) S.-J. Kim, A. Harada, S. Kitamura: Proc. Iron \& Steel Technology Conf. (AISTech 2015), Vol. 3, AISTech, Cleveland, (2015), 3261.

23 D. G. C. Robertson, B. Deo and S. Ohguchi: Ironmaking Steelmaking, 11 (1984), 41.

24) S. Ohguchi, D. G. C. Robertson, B. Deo, P. Grieveson and J. H. E. Jeffes: Ironmaking Steelmaking, 11 (1984), 202.

25) J. H. Park, D. J. Min and H. S. Song: Metall. Mater. Trans. B, 33 (2002), 723.

26) Factsage 7.1, Thermfact/CRCT and GTT-Technologies, 1976-2019.

27) ChemApp, GTT-Technologies, 2003-2019.

28) M. Hino and K. Ito: Thermodynamic Data for Steelmaking, Tohoku University Press, Sendai, (2010), 10.

29) K. Fujii, T. Nagasaka and M. Hino: ISIJ Int., 40 (2000), 1059.

30) J.-I. Kim, S.-J. Kim and S. Kitamura: 7th Int. Congr. on Science and Technology of Steelmaking (ICS2018), AIM, Venice, (2018), CDROM.

31) A. Galindo: Ms. thesis, McMaster University, (2015), https://macsphere. mcmaster.ca/handle/11375/18449, (accessed 2015-10-21).

32) W. R. Paterson and A. N. Hayhurst: Chem. Eng. Sci., 55 (2000), 1925.

33) M. Hirai: ISIJ Int., 33 (1993), 251

34) Verein Deutscher Eisenhüttenleute: Slag Atlas, 2nd ed., Verlag Stahleisen GmbH, Düsseldorf, (1995), 44. 